\title{
波漂流力に及ぼす水底段差の影響について
}

\author{
正員 谷 澤 克 治* 正員 南真 紀子* \\ 正員 沢 田 博 史*
}

\section{EFFECTS OF A SEA FLOOR STEP ON WAVE DRIFT FORCE}

by Katsuji Tanizawa, Member Makiko Minami, Member Hiroshi Sawada, Member

\begin{abstract}
Summary
A linear and a fully nonlinear numerical wave tanks (NWTs) were applied to study wave drift force acts on a two-dimensional Lewis form body in finite depth wave flume. These NWTs are based on potential theory and the fluid and floating body motions are directly simulated in time domain. Boundary value problems both on the velocity potential $\phi$ and its time derivative $\partial \phi / \partial t$ are solved at each time step. The coupling condition between fluid and floating body is imposed as the implicit boundary condition of $\partial \phi / \partial t$ on wetted body surface. The radiation condition at both tank ends are satisfied by artificial damping technique. Using these NWTs, effects of the floor step of the flume on wave drift force were studied. Measurement of wave drift force was also conducted in our two dimensional wave flume. In this report,the results of simulations and measurements are presented and the effect of the floor step on wave drift force is discussed.
\end{abstract}

\section{1. 暂 言}

船舶技術研究所では，特別研究「荒天下航行不能船舶 の漂流防止に関する研究」を海上保安庁, 大阪大学, 九 州大学，製銅会社，サルベージ会社と共同で実施してい る。この研究では，船載型の曳航支援システムの試作が 最終成果のひとつとして期待されている。その一睘とし て, 著者らは様々な条件下で自由浮体に働く波漂流力と 漂流運動について調べており，本報では水底にステップ 状の段差が存在する場合，これが波漂流力にどのように 影響するのかを報告する。本研究は航行不能船舶が沿岸 に漂着して座礁の恐れが生じた場合に，曳船がこれを安

運輸省船舶技術研究所

原稿受理 平成 12 年 1 月 11 日

春季講演会において講演 平成 12 年 5 月 18,19 日
全に曳航するために必要な馬力推定を行うことを目的と しており，浅水域においては水底形状の影響は波漂流力 を正確に推定する上で考虑すべきである。

波漂流力は船舶海洋流体力学の最も古いトピックス のひとつである。研究の初期には，丸尾 ${ }^{1)}$ は，波漂流 力を浮体周辺の波のエネルギーと運動量の保存則の観点 から研究し, 波漂流力が発生する機構に明確な説明を与 えた。Newman ${ }^{2)}$ は, 船舶に作用する波漂流力と定常 Yaw モーメントを導き, Serise 60 の船体形状について それらの值の計算を行った。野尻と村山 ${ }^{3)}$ は，丸尾の 理論を浅水域に拡張し，二次元の水槽実験により検証を 行った。工藤と小林 ${ }^{4)}$ は, 球と回転楕円体に働く波漂流 力の研究を行った。これらの研究により得られた成果は, 多くの研究者や技術者により海洋構造物や船舶に働く波 漂流力の推定に利用されている。これらの研究を踏まえ， 著者らは沿岸海底地形の最も簡単な例としてステップ状 の段差を取り上げ，これが波漂流力に与える影響を理論， 実験, 数值計算の 3 面から研究した。この基礎的研究で 
は, 浮体としてルイスフォーム断面形状を有する 2 次元 浮体を用いた。著者らは以前の研究 ${ }^{11)}$ で，この2次元 浮体について時間領域非線形シミュレーション法を用い た波漂流力の推定を行い，推定結果が野尻らの線形理論 から得られた值や実験值 ${ }^{3)}$ とよく一致することを示し た。そこで，本研究では非線形シミュレーション法と共 に, 計算速度の速い線形シミュレーション法をパラメー タースタディに用いて段差影響を調べた。

\section{2. 波と漂流力との理佥関係式}

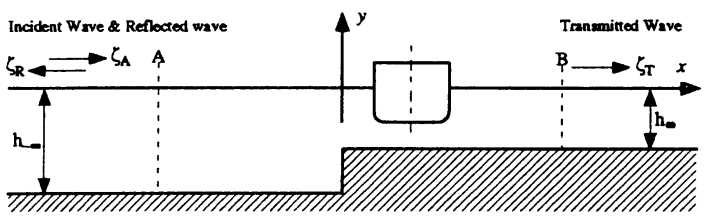

Fig.1 Wave flume with a bottom step

Fig.1 に $x=0$ において水底に段差を有する 2 次元 水路を示す。段差の両側の水深は左右それぞれ $h_{-\infty}$ と $h_{\infty}$ である。入射波は， $x=-\infty$ から $\infty$ に伝播する。 段差と浮体により波のエネルギーの一部は反射し，残り は $x=\infty$ 一透過する。この研究では，理想流体を仮定 し，浮体によるエネルギーの散逸はないものとする。ま た，波浪場は周期的定常状態にあるものとする。よって， 入射波，反射波，透過波の波高 $\zeta_{A}, \zeta_{R} ， \zeta_{T}$ は時間的, 空間的に一定値をとる。

波エネルギー $E$ は,

$$
E=\frac{1}{2} \rho g \zeta^{2}
$$

と表現でき，波振幅 $\zeta$ の関数で水深 $h$ に依存しない。し かし，波の群速度 $V$ は，次のように水梁に依存する。

$$
\begin{aligned}
V & =V_{c} n \\
V_{c} & =\frac{\omega}{k} \\
n & =\frac{1}{2}\left(1+\frac{2 k h}{\sinh 2 k h}\right)
\end{aligned}
$$

ここで， $V_{c}$ は波の位相速度， $\omega$ と $k$ はそれぞれ波周波 数と波数， $n$ は波の群速度と位相速度との比である。

検查面 A，B にはさまれた領域における波エネルギー の保存則より,

$$
\left(E_{A}-E_{R}\right) V_{-\infty}=E_{T} V_{\infty}
$$

が成り立つ。ここで， $E_{A} ， E_{R} ， E_{T}$ はそれぞれ入射波， 反射波，透過波のエネルギーであり， $V_{ \pm \infty}$ は $x= \pm \infty$
における群速度である。(1) 式～(4) 式を (5) 式に代入 することにより次の関係式を得ることができる。

$$
\frac{n_{-\infty}}{k_{-\infty}}\left(\zeta_{A}^{2}-\zeta_{R}^{2}\right)=\frac{n_{\infty}}{k_{\infty}} \zeta_{T}^{2}
$$

一方，波漂流力 $F_{D}$ は反射波の振幅を用いて，

$$
F_{D}=n_{-\infty} \rho g \zeta_{R}^{2}
$$

で与えられることが知られている。そこで，(6)(7) 式よ り, 次の理論的な入射波，反射波，透過波と波漂流力の 関係式が得られる。

$$
\begin{aligned}
\frac{F_{D}}{\frac{1}{2} \rho g \zeta_{A}^{2}}= & 2 n_{-\infty}\left(\frac{\zeta_{R}}{\zeta_{A}}\right)^{2} \\
= & n_{-\infty}\left\{1+\left(\frac{\zeta_{R}}{\zeta_{A}}\right)^{2}\right\} \\
& -n_{\infty} \frac{k_{-\infty}}{k_{\infty}}\left(\frac{\zeta_{T}}{\zeta_{A}}\right)^{2} \\
= & 2 n_{-\infty}\left\{1-\frac{k_{-\infty}}{k_{\infty}} \frac{n_{\infty}}{n_{-\infty}}\left(\frac{\zeta_{T}}{\zeta_{A}}\right)^{2}\right\}
\end{aligned}
$$

\section{3. 数值計算法の棫要}

\section{1 非楾形数值造波水槽}

自由表面 $S_{f}$ ，水槽左端壁面の造波機面 $S_{w}$ ，ステッ プを有する水槽底面 $S_{b}$, 水槽右端壁面 $S_{s}$ を境界とす る2次元造波水槽を考える。本造波水槽では， $x$ 軸を静 止時の自由表面にとり, 上方向を $z$ の正とする空間固定 座標系 $o-x z$ を用い, 計算は重力加速度 $g$, 流体密度 $\rho$ ，入射する規則波の波長 $\lambda$ を用いて無次元化している。 流体は均質で，非圧縮，非粘性，流れは非回転と仮定す る。流体の運動は速度ポテンシャル $\phi$ 及び，その時間 偏微分 $\partial \phi / \partial t \equiv \phi_{t}$ で表現される。 $\phi$ と $\phi_{t}$ は流体領 域内でラプラスの式を満足する。

$$
\nabla^{2} \phi=\nabla^{2} \phi_{t}=0
$$

$\phi$ と $\phi_{t}$ にグリーンの恒等式を適用すると，2 次元問題 では $\ln r$ を核関数に用いて,

$$
\begin{aligned}
& c(\mathcal{Q})\left\{\begin{array}{l}
\phi(\mathcal{Q}) \\
\phi_{t}(\mathcal{Q})
\end{array}\right\} \\
& =\int_{S}\left\{\begin{array}{l}
\phi(\mathcal{P}) \\
\phi_{t}(\mathcal{P})
\end{array}\right\} \frac{\partial}{\partial n} \ln r(\mathcal{P}, \mathcal{Q}) \\
& -\ln r(\mathcal{P}, \mathcal{Q})\left\{\begin{array}{l}
\frac{\partial \phi(\mathcal{P})}{\partial n} \\
\frac{\partial \phi_{t}(\mathcal{P})}{\partial n}
\end{array}\right\} d S
\end{aligned}
$$


が成り立つ。こで, $\mathcal{P}, \mathcal{Q}$ は境界上の点, $n$ は流体領域 外向きの法線方向, $r(\mathcal{P}, \mathcal{Q})$ は点 $\mathcal{P} \mathcal{Q}$ 間の距離, $c(\mathcal{Q})$ は，点 $\mathcal{Q}$ における境界の角度である。

造波機面 $S_{w}$ では，境界条件として線形波のフラック スを与える。

$$
\begin{aligned}
\frac{\partial \phi}{\partial n} & =-\frac{k \zeta_{A} \cosh k(z+h)}{\omega \cosh k h} \cos (k x-\omega t) \\
\frac{\partial \phi_{t}}{\partial n} & =-\frac{k \zeta_{A} \cosh k(z+h)}{\cosh k h} \sin (k x-\omega t)
\end{aligned}
$$

ここで， $k ， \omega ， \zeta_{A}$ はそれぞれ入射波の波数，角周波数， 波振幅である。自由表面の幾何学的境界条件と力学的境 界条件は，

$$
\begin{aligned}
\frac{D \phi}{D t} & =-z+\frac{1}{2}(\nabla \phi)^{2}-\nu(x)\left(\phi-\phi_{e}\right) \\
\frac{D \boldsymbol{x}}{D t} & =\nabla \phi-\nu(x)\left(\eta-\eta_{e}\right)
\end{aligned}
$$

で与えられる。ここで, $\eta$ は水面変位, $\nu(x)$ は减衰係数,

$$
\nu(x)=\left\{\begin{array}{c}
\alpha \omega\left(\frac{x-x_{0}}{\lambda}\right)^{2} \\
\text { for } x_{0} \leq x \leq x_{1}=x_{0}+\beta \lambda \\
0 \quad \text { for } x<x_{0} \text { or } x>x_{1}
\end{array}\right.
$$

で，减衰領域内の自由表面条件に人工的な减衰項が付加 されている。减衰俰数に含まれる $\alpha$ は减哀項の強さ， $\beta$ は减衰領域の長さを調節する無次元パラメータである。 减衰項は， $\alpha \simeq 1, \beta \geq 1$ で効率よく規則波を吸収し，波 の反射率は波高比で $2 \%$ 以下である。 $\phi_{e}$ と $\eta_{e}$ は速度 ポテンシャルと自由表面変位の参照値であり, 减衰項は この参照値加の差 $\phi-\phi_{e}, \eta-\eta_{e}$ を减衰させるよう に働く。减衰領域を固定壁の前に置き，単純な消波ビ一 チとする場合は，参照值を $\phi_{e}=0, \eta_{e}=0$ とする。一 方, 造波機側に減衰領域を置き吸収式造波機として働か せる場合は，参照値を

$$
\begin{aligned}
& \phi_{e}=\frac{\zeta_{A} \cosh k(h+z)}{\omega \cosh k h} \sin (k x-\omega t) \\
& \eta_{e}=\zeta_{A} \cos (k x-\omega t)
\end{aligned}
$$

とする。

物体表面の $\phi$ に関する幾何学的境界条件は，

$$
\frac{\partial \phi}{\partial n}=\boldsymbol{n} \cdot\left(\boldsymbol{v}_{0}+\boldsymbol{\omega} \times \boldsymbol{r}\right)
$$

となる。ここで， $\boldsymbol{v}_{0}$ と $\boldsymbol{\omega}$ はそれぞれ物体の速度と角速 度である。物体表面の $\phi_{t}$ に関する幾何学的境界条件は,

$$
\frac{\partial \phi_{t}}{\partial n}=-k_{n}\left(\nabla \phi-\boldsymbol{v}_{o}-\boldsymbol{\omega} \times \boldsymbol{r}\right)^{2}
$$

$$
\begin{aligned}
& +n \cdot\left(\dot{v}_{o}+\dot{\omega} \times r\right)+n \cdot \omega \times(\omega \times r) \\
& +n \cdot 2 \omega \times\left(\nabla \phi-v_{o}-\omega \times r\right) \\
& -\frac{\partial}{\partial n}\left(\frac{1}{2}(\nabla \phi)^{2}\right)
\end{aligned}
$$

で与えられる。ここで， $k_{n}$ は物体表面の曲率であり， $\dot{\boldsymbol{v}}_{\boldsymbol{o}}, \dot{\boldsymbol{\omega}}$ はそれぞれ物体の加速度と回転角加速度である ${ }^{7)}$ 。 浮体表面において, $\dot{\boldsymbol{v}}_{o}$ と它は変動圧 $\phi_{t}$ の関数である ため, 陽に計算できない。しかし，浮体の運動方程式を 用いることにより， $\dot{v}_{o}$ と㐫を(21) 式から消去して陰な 浮体表面の境界条件が得られる。浮体の慣性テンソルを $\mathcal{M}$ ，一般化法線方向ベクトルを $N=(n, n \times r)$ とす ると，陰境界条件式は，

$$
\begin{aligned}
& \frac{\partial \phi_{t}}{\partial n}=N \mathcal{M}^{-1} \int_{S_{s}}-\phi_{t} N d s \\
& +N \mathcal{M}^{-1}\left\{\int_{S_{s}}\left(-z-\frac{1}{2}(\nabla \phi)^{2}\right) N d s+F_{g}\right\} \\
& +q-\frac{\partial}{\partial n}\left(\frac{1}{2}(\nabla \phi)^{2}\right)
\end{aligned}
$$

となる。ここで, $\boldsymbol{F}_{\boldsymbol{g}}$ は重力や倸留力等の浮体に働く外 力の和である。 $q$ は速度場の解から陽に求められる項で,

$$
\begin{aligned}
q & =-k_{n}\left(\nabla \phi-\boldsymbol{v}_{o}-\boldsymbol{\omega} \times \boldsymbol{r}\right)^{2} \\
& +\boldsymbol{n} \cdot \boldsymbol{\omega} \times(\boldsymbol{\omega} \times \boldsymbol{r}) \\
& +\boldsymbol{n} \cdot 2 \boldsymbol{\omega} \times\left(\nabla \phi-\boldsymbol{v}_{\boldsymbol{o}}-\boldsymbol{\omega} \times \boldsymbol{r}\right)
\end{aligned}
$$

である。これらの境界条件下， $\phi$ と $\phi_{t}$ に関するグリー ンの恒等式を境界要素法を用いて数值的に解いて $\phi$ と $\phi_{t}$ の值を求めることができる。この計算法では時間積 分に 4 次のルンゲ・クッタ法を用い，流体と浮体の運動 を時間領域でシミュレートしている。また，自由表面の 追跡には混合オイラーラグランジェ法 (MEL) を用いて いる。

\section{2 線形数值造波水格}

線形の数値造波水槽は，境界条件を除いて非線形の 数值造波水槽とほほ同じ数值シミュレーション法であ る。線形の数值造波水槽では, 自由表面の境界条件式 (15)(16) は線形化され,

$$
\begin{aligned}
& \frac{\partial \phi}{\partial t}=-z-\nu\left(x_{e}\right)\left(\phi-\phi_{e}\right) \\
& \frac{d z}{d t}=\frac{\partial \phi}{\partial z}-\nu\left(x_{e}\right)\left(\eta-\eta_{e}\right)
\end{aligned}
$$

となる。 $\phi_{t}$ についての物体表面の境界条件式 (21) と物 体表面の陰の境界条件式 (22) も線形化され,

$$
\frac{\partial \phi_{t}}{\partial n}=n \cdot\left(\dot{v}_{o}+\dot{\omega} \times r\right)
$$


と

$$
\frac{\partial \phi_{t}}{\partial n}=N \mathcal{M}^{-1}\left\{\int_{S_{s}}\left(-\phi_{t}-z\right) N d s+F_{g}\right\}
$$

となる。線形化により，境界形状は調和振動の平均の位 置に固定できるため, 時間ステップ毎に境界要素行列を 再計算する必要がなく, 線形シミュレーションは, 非線 形シミュレーションと比較して計算速度がきわめて速い。 また, 周波数領域の解法と同程度の精度を有し, 様々な 線形問題に適用できる。非線形計算, 線形計算ともにシ ミュレーションは静止状態から始め, 浮体の運動や波浪 場が周期的定常状態に収束するまで継続した。

\section{4. 水棈実験}

\subsection{2次元水棈}

実験は船舶技術研究所海洋開発工学部の浅水 2 次元水 槽 $($ 長さ $=26 \mathrm{~m}$, 幅 $=0.5 \mathrm{~m}$, 水深 $=0.5 \mathrm{~m})$ において実施 した。水槽の右半分の部分には厚さ $10 \mathrm{~mm}$ の㴊なアル ミ板とコンクリートブロックを用いて高さ $20 \mathrm{~cm}$ の昇床 を構築し, 左半分の水深が $0.5 \mathrm{~m}$, 右半分の水深が $0.3 \mathrm{~m}$ となるようにした。また段差部は板で被い，波のエネル ギーが昇床の下へ入り込まないようにした。本水槽の左 端には吸収式造波機が，右端には消波ビ一チが備えられ ている。吸収式造波機のエネルギ一吸収率は，周波数に も依るが平均して 95\%である。この值は，造波機と浮体 の間の波の多重反射を含めた周期的に定常な波浪場を得 るのに十分である。水面の上下動は，7個の波高計を用 いて計測し，合田の方法 ${ }^{5)}$ を用いて入射波と反射波を分 離した。

\section{2 浮体と計瀴装置}

ルイスフォーム断面形状を有する 2 次元模型を実験に 用いて波漂流力の計測を行った。Table 1 に主要目を示 す。Fig.2 に示すように, 浮体はジンバル, ロードセル, ヒーブロッド, キャリッジで構成された動摇計測装置に 取り付けられ，漂流を避けるため水平方向にだけ弱いバ ネで係留されている。計測項目は3 自由度の浮体運動, 波浪場, 波漂流力である。波漂流力はヒーブロッドとジ ンバルとの間に取り付けたロードセルを用いて直接測定 した。水平方向に掛かる力の平均值が波漂流力である。

\section{5. 轺 果}

本報では，以下の図中に，線形計算によるものを実線， 実験と非線形計算によるものを記号で示す。
Table 1 Principle Dimensions

\begin{tabular}{|l|c|r|c|}
\hline Breadth & $B$ & 0.40 & $\mathrm{~m}$ \\
\hline Draft & $d$ & 0.20 & $\mathrm{~m}$ \\
\hline $\begin{array}{c}\text { Lewis form } \\
\text { parameter }\end{array}$ & $H_{0}$ & 1.00 & \\
\cline { 2 - 4 } & $\sigma$ & 1.00 & \\
\hline Metacenter height & $G M$ & 0.055 & $\mathrm{~m}$ \\
\hline $\begin{array}{c}\text { Displacement } \\
\text { /Length }\end{array}$ & $W$ & 80.0 & $\mathrm{~kg} / \mathrm{m}$ \\
\hline Radius of gyration & $\sqrt{I_{y y} / W}$ & 0.13 & $\mathrm{~m}$ \\
\hline Natural roll period & $T_{r}$ & 1.23 & $\mathrm{sec}$ \\
\hline
\end{tabular}

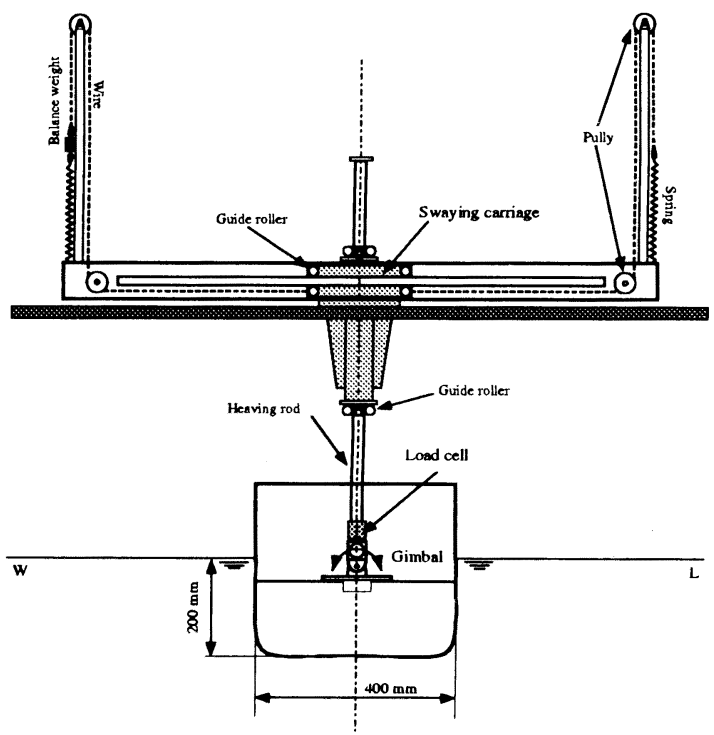

Fig.2 Floating Body and Measuring Equipment

\section{1 段差に畧く波漂流力}

段差自体に働く波漂流力を得るため, 浮体のない状態 での計測を行った。Fig.3(a) に段差による波の反射係 数と透過係数の計算值を計測值と比較して示す。横軸は, 無次元化波数 $k_{-\infty} B / 2$ である。本報では浮体の半幅 $B / 2=0.2 m$ を代表寸法として用いた。全般的に反射 係数の計算値と計測值はよく一致している。透過係数は, 短波長域, $k_{-\infty} B / 2>1.5$, で, 計測值が計算值よりも 小さくなっている。これは段差上での弱い砕波によるも のである。一方, 長波長域, $k_{-\infty} B / 2<0.5$, での透過 係数は, 計測值, 計算値ともに 1 を超えている。もし水 深が一定であれば，透過俰数が 1 を超えることはない。 しかし，(6) 式が意味するように，もし水深が $x_{ \pm \infty}$ に おいて異なっていれば，1 を超えることもあり得る。線 形の数值計算による波の反射係数と透過係数は (6) 式を 


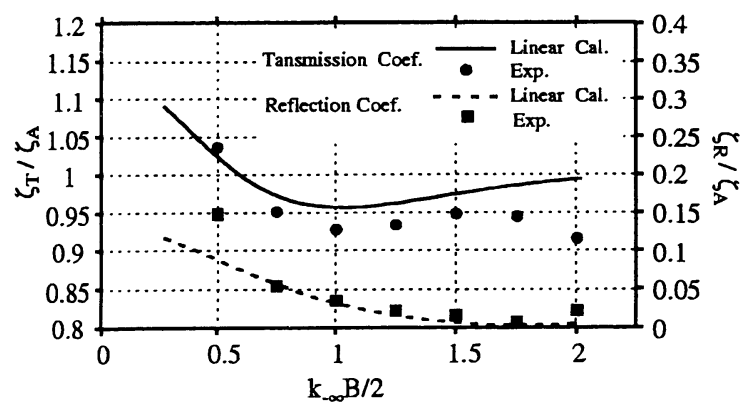

(a) Tansmission and Reflection Coef. of bottom step

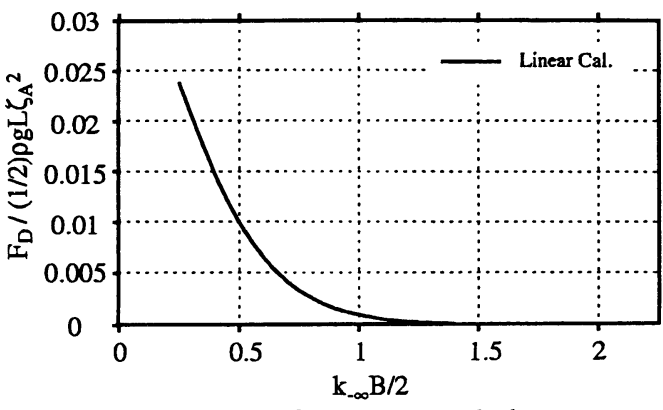

(b) Wave Drift Force acts on the bottom step

Fig.3 Wave reflection, transmission and drift force by the floor step itself

満たしており，計測值とも良く一致している。Fig.3(b) に (9) 式と数值計算結果加推定した段差に働く波漂流 力を示す。段差自体に働く波漂流力は長波長域において も非常に小さい值である。

\section{2 浮体に俱く波漂流力}

本報では，波数と浮体の段差に対する相対的な位置を 主なパラメータとした。しかし，実験では装置の制約か ら次の 3 力所での計測となった。

1. 段差上 $(x=0 m)$

2. 段差より $1 m$ 波上側 $(x=-1 m)$

3. 段差より $1 m$ 波下側 $(x=1 m)$

浮体の位置による波漂流力の詳細な検討は線形数值計算 により行った。Fig.4に $x=0 m$ に浮体がある場合の 計測值と非線形，線形のそれぞれの計算結果を比較して 示寸。実験では浮体中心線の平均位置が概ね水底段差部 の真上に来るように，重りを用いて浮体位置を調節した。 非線形計算においても，弱い線形倸留力に加え水平方向 に一定の力を掛けて, 浮体の位膡がほぼ $x=0 m$ になる ように調節した。Fig.4(a,b,c) は, 浮体運動の振幅と位 相を示している。全般的に, 運動の計算値と計測值はよ く一致している。Fig.4(d,e) は, 波の反射係数と透過係 数を示している。短波長領域で反射係数の計算值が計測 値を上回っているが，これは波上側の浮体表面と自由表 面との交線近傍で弱い砕波が発生しているためと思われ る。一方，透過保数の計算值は計測値と良く一致してい る。Fig.4(f) は，浮体に働く波漂流力を示している。計 算値と計測值はよく一致している。計測值はヒーブロッ ドとジンバルとの間に取り付けたロードセルを用いて直 接測定した值である。計算值は，計算で得られた透過係 数と反射係数を (9) 式に代入して求まる浮体と段差の両 方に㗢く波漂流力から，Fig.3(b) に示した段差単体に 働く波漂流力を差し引いて計算した值である。浮体表面 の圧力積分により波漂流力を直接求めることもできるが，

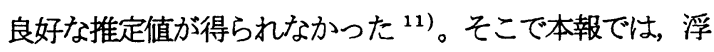
体から離れた波浪場の計算結果から波漂流力を推定した。

Fig.4 から非線形計算が線形計算とほほ同じ結果とな ることがわかる。これは波漂流力が概ね波振幅の 2 乗に 比例していることを意味し, 砕波が起こらない限りは険 しい波でも高次の影響は顕著ではない。つまり, 線形計 算でも波漂流力の推定に十分であると考えられる。Fig.5 と Fig.6 はそれぞれ $x=1 m, x=-1 m$ の場合に ついて Fig.4 と同様の比較を行ったものを示している。 計算値は線形計算のみである。計測值と計算値はこれら の場合についても全般的によく一致している。Fig.4,5,6 から，波漂流力の計算值は信頼がおけると考えられる。

そこで次に，線形計算により波漂流力に対する水底 段差の影響を詳しく評価した結果を示す。Fig.7 に波 周波数を固定して, 浮体と段差との相対位置を変化さ せた場合の波漂流力の変化を示す。この図の横軸は浮 体の中心線の段差に対する相対位置で，左右に一波長 分, $\lambda_{-\infty} \leq x \leq \lambda_{\infty}$, の領域をとっている。波周波 数が $4.772 \mathrm{rad} / \mathrm{sec}$ の場合には, 浮体が段差を越えて 浅い領域に入ると波漂流力が顕著に増加している。ま た，この場合には位置により漂流力が 2 分の 1 波長， $\lambda_{ \pm \infty} / 2$, で周期的に変化している。一方, 波周波数が $5.345 \mathrm{rad} / \mathrm{sec}$ の場合には, 波漂流力はどの位置でも非 常に大きく，位㯰による変化は顕著ではない。このよう に，段差の影響は波周波数によって変わる。そこで全体 像を把握するため, Fig.8 に波漂流力を波数 $k_{-\infty} B / 2$ と浮体と段差との相対位置 $k x$ の関数として 3 次元的に 示す。この図からは長波長域, $k_{-\infty} B / 2<0.6$, でか 浅い領域， $x>0$, で段差の影響が顕著であることが明 確に読みとれる。この波長と領域では，波漂流力は振動 し，いくつかのピークが現れるが，ピーク值自体はより 短波長側に存在する最大值よりは小さい。浮体の相対位 置に関わらず波漂流力が急激に大きくなっている波周波 数は，ロールの共振周波数にあたり，またこの計算では 
(a) Sway

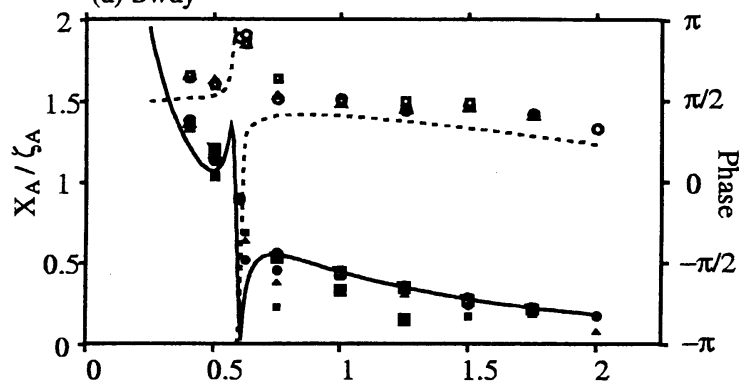

(b) Heave

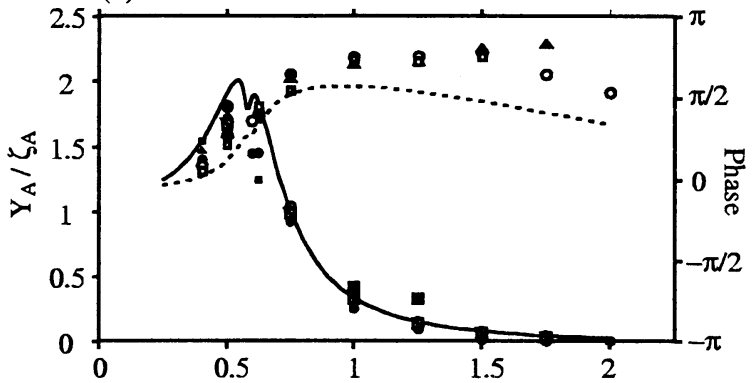

(c) Roll

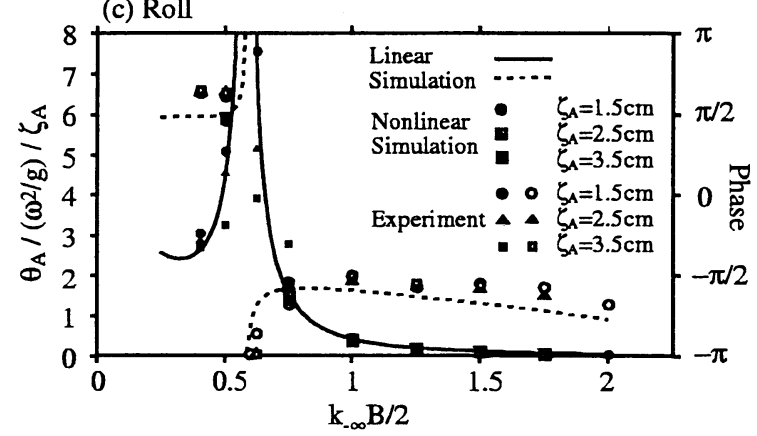

(d) Reflection Coefficient

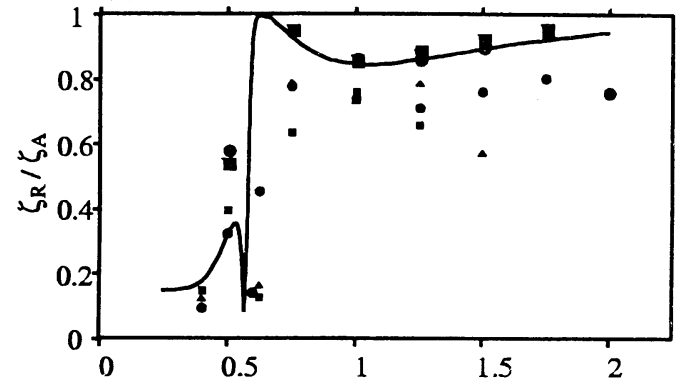

(e) Transmission Coefficient

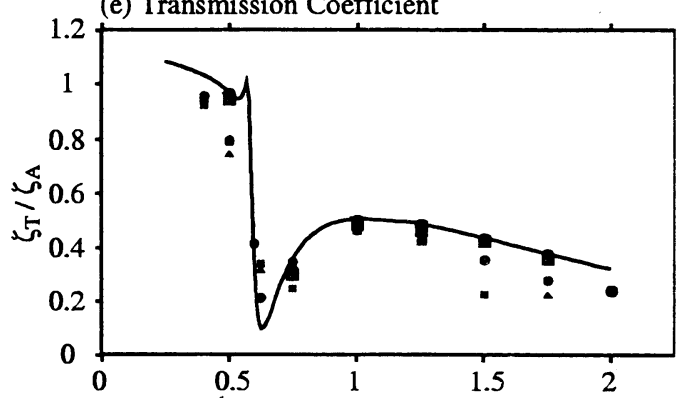

(f) Wave drift Force acts on the body

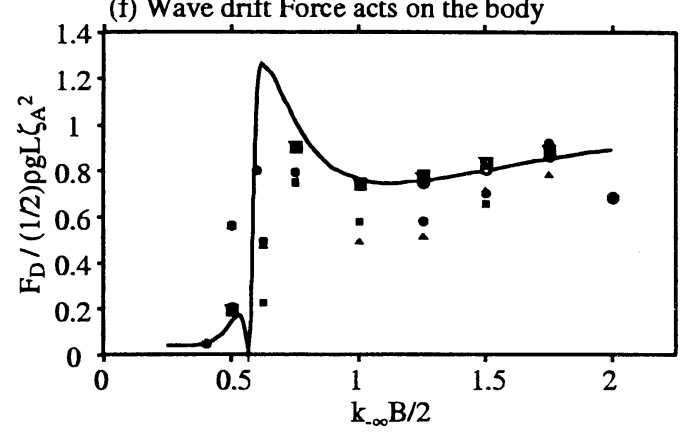

Fig.4 Floating body motions, wave reflection and transmission coefficients and wave drift force at $x=0 m$.

ヒーブの共振周波数もほぼ同じ周波数である。この共振 点から長波長側は急激な変化があるが, 短波長側はなだ らかな変化を示す。段差の影響は短波長側ではほとんど 見られない。

\section{6. 結 言}

線形と非線形の数值造波水槽を 2 次元浮体の波漂流力 の推定に用い，浮体に作用する波漂流力に対する水底段 差の影響を理論, 数值計算, 実験の 3 面から研究した。 以下の項目は，これまでの研究で得られた主な結果で ある。

1. 水底段差が存在する場合の入射波, 反射波, 透過 波, 波漂流力の間に成り立つ理論的な関係式を求 めた。
2. これまでに開発してきた非線形数值造波水槽を ベースに，水底段差が存在する場合にも適用可能 で高速な汎用線形計算法を開発し，浮体の線形動 摇と浮体周りの線形波浪場の計算を実施した。

3. 本計算法による浮体の線形動摇と浮体周りの線 形波浪場の計算結果は, 非線形計算法による結果 や，計湘值と全般的によく一致した。

4. 波漂流力についても計算値と計測值はよく一致 した。

5. 段差の影響は, 段差上の浅い領域， $x>0$ ，におい て, 波数が浮体の共振点より低い場合, $k_{-\infty} B / 2<$ 0.6，に顥著であることがわかった。 波漂流力に及ぼす段差影響をより詳細に検討するために は，浮体表面の圧力積分により波漂流力を精度よく推定 


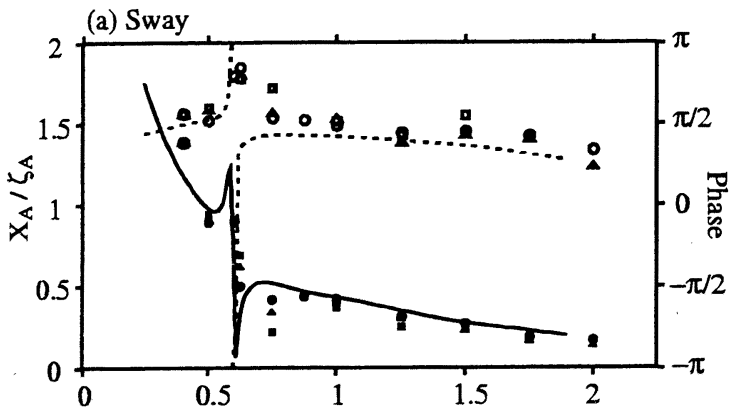

(b) Heave

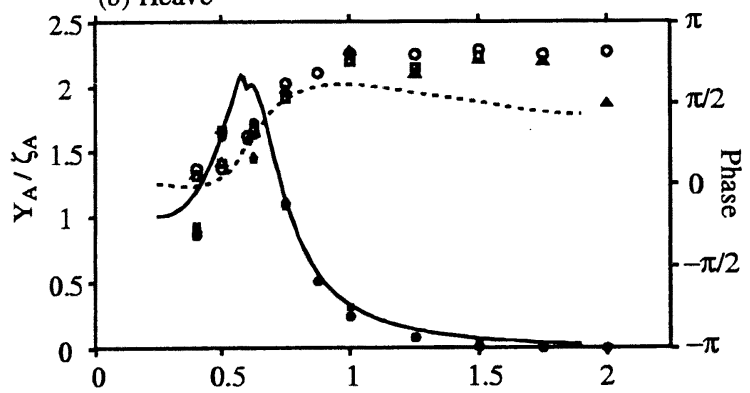

(c) Roll

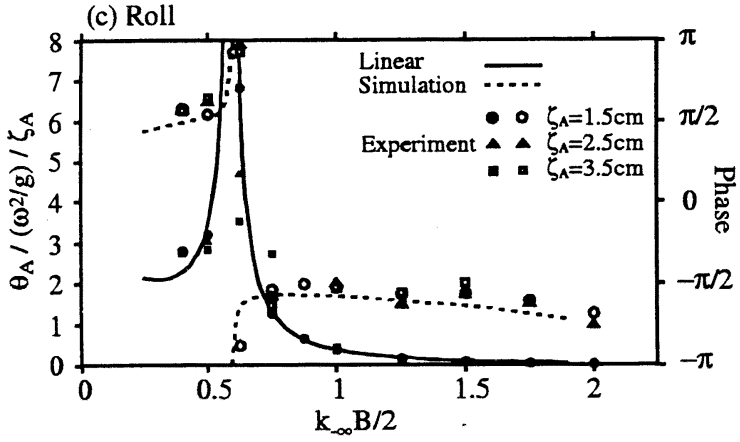

(d) Reflection Coefficient

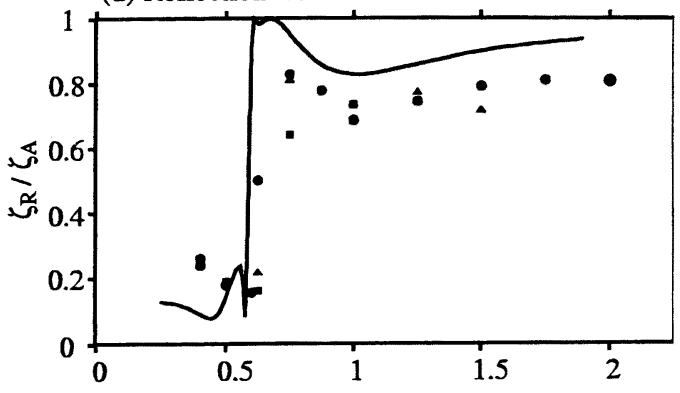

(e) Transmission Coefficient

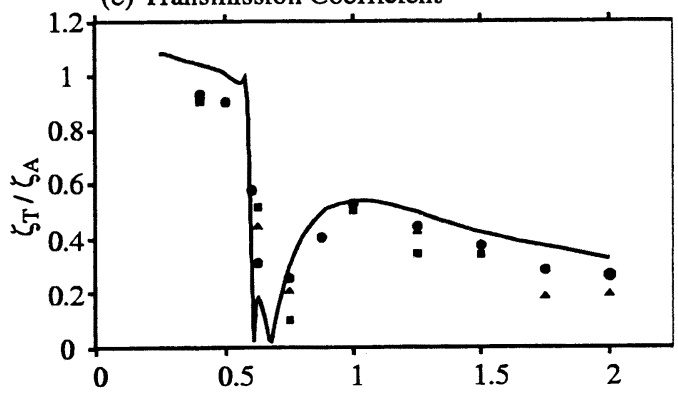

(f) Wave drift Force acts on the body

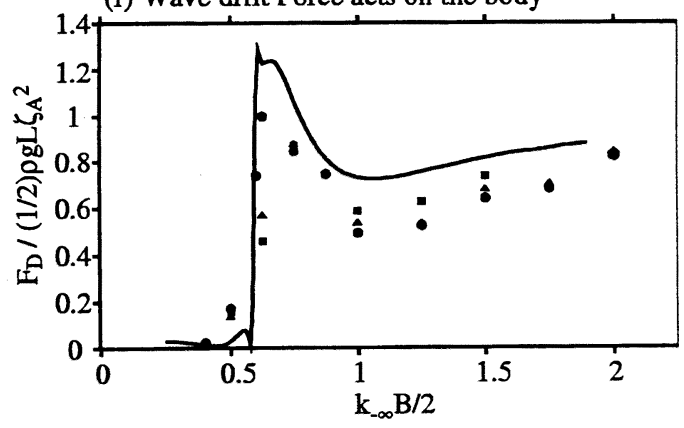

Fig.5 Floating body motions, wave reflection and transmission coefficients and wave drift force at $x=-1 m$.

する必要があり，これには数值造波水槽の精度の改善が 必要である。一般に，波漂流力は小さく，1次の波力成 分に比べ数值計算の精度は良くない。しかし，著者らの 非線形数値計算法により求めた 2 次及び 3 次の波力の振 動成分は，他の数值計算法ならびに実験值との比較によ り，正確であることが確かめられている ${ }^{12) 。 2}$ 次の定 常成分の計算精度だけに問題があるようで, 現在数值計 算コードを細部にわたって調べ，本質的な原因を見つけ ようとしているところである。

\section{考文献}

1) Maruo,H. : The drift of a body floating on waves, J.S.R., Vol.4, No.3, (1960)

2) Newman,J.N.: The drift force and moment on ships in waves, J.S.R., Vol.11, No.1, (1967)
3）野尻信弘，村山敬一：規則波中の 2 次元浮体に働 く波漂流力に関する研究，西部造船協会々報，第 51 号, (1975)

4) 工藤君明，小林一也：三次元物体の波による漂 流力 (第 1 報, 第 2 報)，船論，第 $141 ， 144$ 号， $(1977,1978)$

5) 合田良実, 鈴木康正, 岸良安治, 菊池治 : 不規則波 実験における入 ・ 反射波の分離測定法，港湾技研資 料, vol.248,pp3-24, (1976)

6) Cointe,R.,Geyer,P.,King,B.,Molin,B. and

Tramoni,M. : Nonlinear and linear motions of a rectangular barge in perfect fluid, Proc. of the 18th Symp. on Naval Hydro., AnnArbor, Michigan, pp85-98, (1990)

7) Tanizawa, K. : A Nonlinear Simulation 
(a) Sway

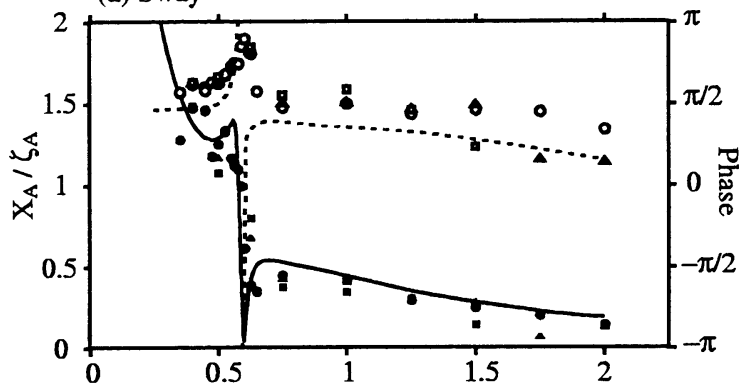

(b) Heave

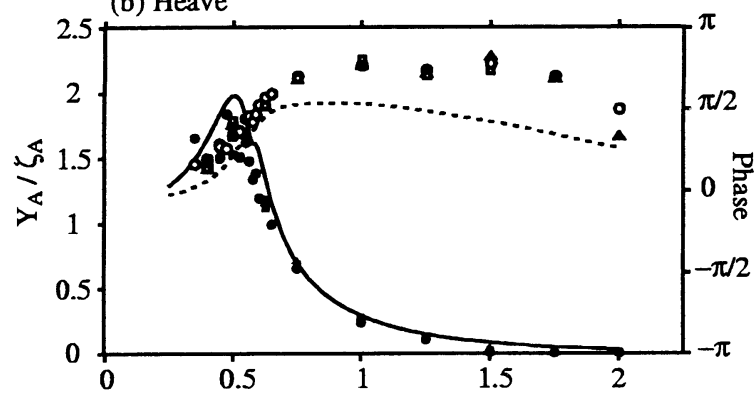

(c) Roll

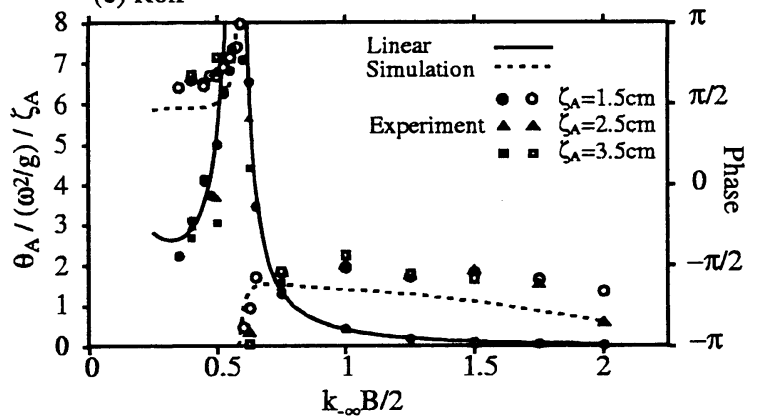

(d) Reflection Coefficient

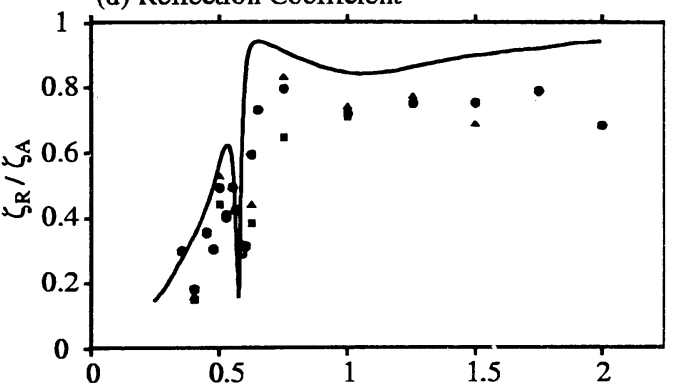

(e) Transmission Coefficient

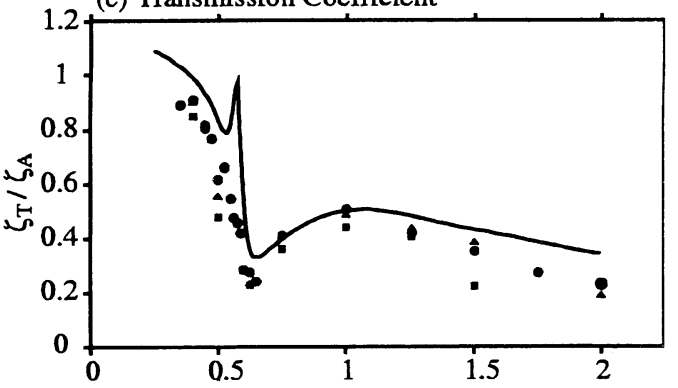

(f) Wave drift Force acts on the body

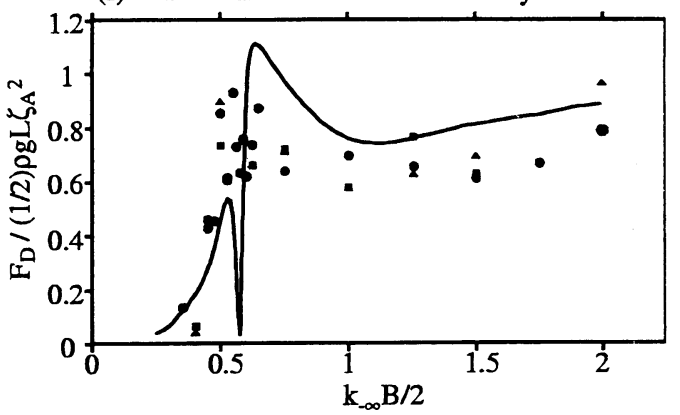

Fig.6 Floating body motions, wave reflection and transmission coefficients and wave drift force at $x=1 m$.

Method of 3-D Body Motions in Waves, 日 本造船学会論文集, 第 178 号, pp179-191，(1995)

8) Kashiwagi,M. : Full-nonlinear simulation of hydrodynamic forces on a Heaving twodimensional body，日本造船学会論文集，第 180 号, pp373-381, (1996)

9) Tanizawa,K. : Long time fully nonlinear simulation of floating body motions with artificial damping zone，日本造船学会論文集，第 180 号, pp311-319, (1996)

10) Tanizawa, K. and Naito, S. : A study on parametric roll motions by fully nonlinear numerical wave tank, Proc. of 11th ISOPE Conf., Honolulu, Hawaii, Vol.3, pp69-75, (1997)
11) Tanizawa,K., Minami,M. and Naito,S. : Estimation of wave drift force by numerical wave tank Proc. 9th ISOPE Conf., vol.3, Brest, (1999)

12) Tanizawa, K. and Clment, $A$ : The report of NWT workshop, Proc. 10th ISOPE Conf., vol.3, Seattle, (2000) 

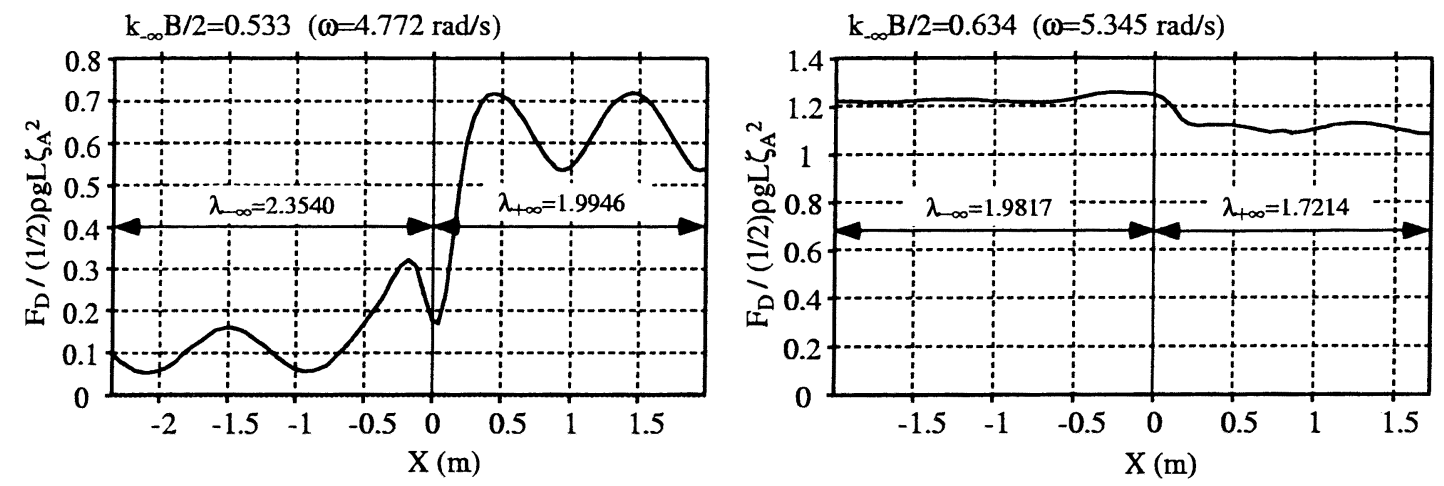

Fig.7 Wave drift force as a function of relative location of the body to the floor step

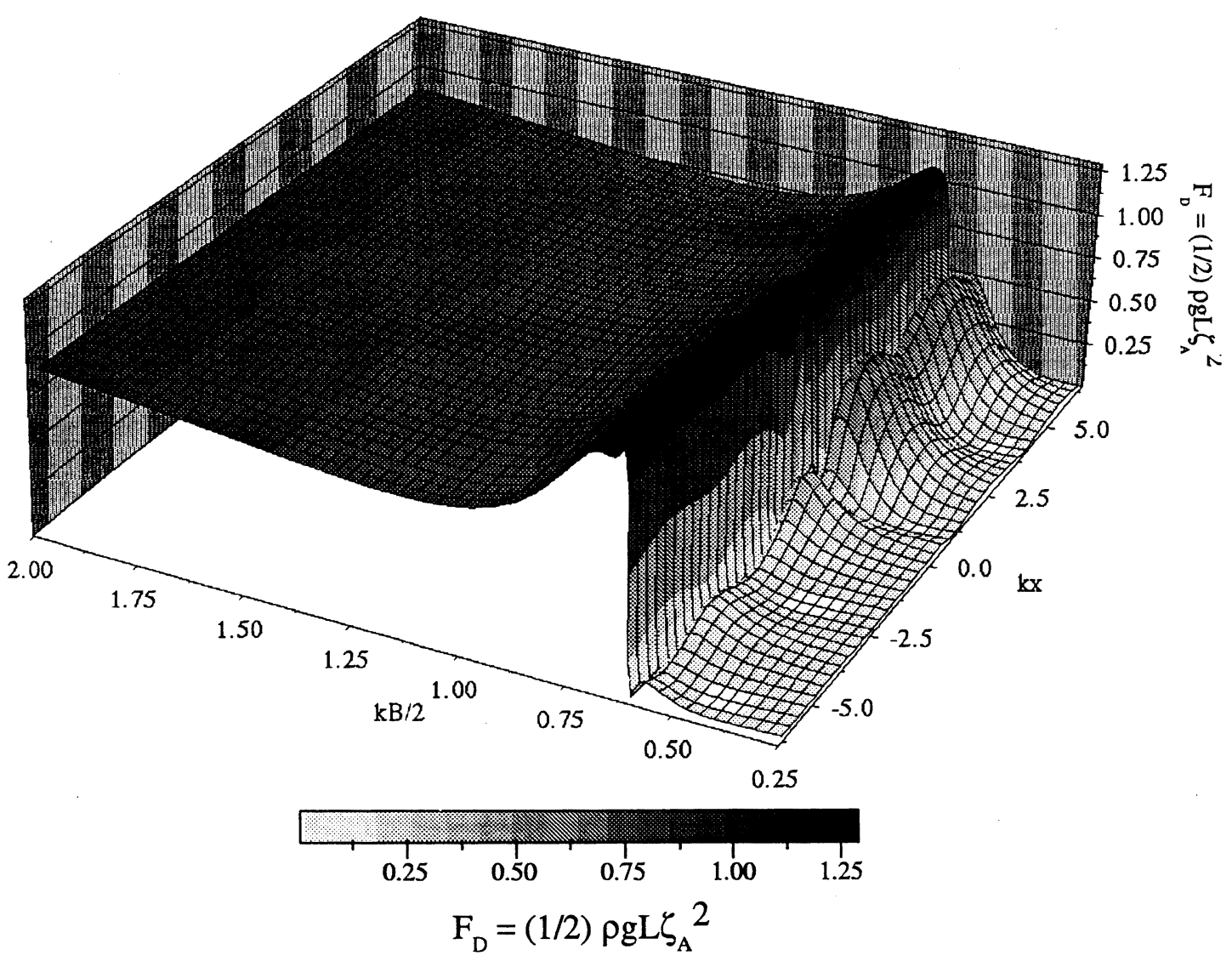

Fig. 8 Wave drift force as a function of wave number and relative location of the body to the floor step 